Sveto Purić ${ }^{1}$

Faculty of Law, University of Kragujevac

Dušan Jerotijević ${ }^{2}$

Faculty of Business and Industrial Management

University Union in Belgrade
SCIENTIFIC REVIEW ARTICLE

doi:10.5937/ekonomika1503121P

Received: June 8, 2015

Accepted: September 2, 2015

\title{
THE STRUCTURE OF EXPORTS AND IMPORTS ASA A LIMITING FACTOR IN IMPROVING THE COMPETITIVENESS OF REPUBLIC SERBIA
}

\begin{abstract}
The aim of this work was to determine the regression analysis, which are products in the five-year period had the greatest impact on the values of exports and imports (measured in thousands of US \$), and perform a comparative analysis of the results. The analysis, using statistical and econometric methodology, included the 30 commodity groups to stop imports and 30 commodity groups in exports with a share of more than US $\$ 100$ million in the period from 2009 to 2013. The paper consists of four consistent whole. The first relates to the analysis of the main indicators of competitiveness, in order to show the importance of foreign trade deficit movement in the overall competitiveness of a country. The second and third part of the paper deals with the analysis of exports and imports by commodity groups and allocation of goods that have the greatest impact on their movements in the period. In the fourth part of the work was done on the basis of a comparative analysis of the results obtained from the regression analysis.
\end{abstract}

Key words: export, import, trade groups, competition, agriculture

JEL Classification: F10, O11, C12, C87

\section{СТРУКТУРА ИЗВОЗА И УВОЗА КАО ОГРАНИЧАВАЈУЋИ ФАКТОР У ПОБОЉШАҢУ КОНКУРЕНТНОСТИ СРБИЈЕ}

Циљ рада је да се регресионом анализом утврди који су то производи у петогодишњем периоду имали највећи утицај на кретање вредности извоза и увоза (мерено у хиљадама УС\$), и изврши упоредна анализа добијених резултата. Анализа, помоћу статистичко-економетријске методологије, обухватила је 30 робних група на стани увоза и 30 робних група на страни извоза са учешћем већим од 100.000.000 УС\$ у периоду од 2009. до 2013. године. Рад се састоји од четири конзистентне иелине. Прва се односи на анализу основних индикатора конкурентности, како би се указала важност кретања спољнотрговинског дефиџита у укупној оцени конкурентности једне земье. Други и трећи део рада односи се на анализу извоза и увоза по

\footnotetext{
${ }^{1}$ spuric@jura.kg.ac.rs

2 dusanjerotijevic@gmail.com
} 
робним групама и издвајање роба које имају највећи утицај на њихово кретање y посматраном периоду. У четвртом делу рада урађена је компаративна анализа на основу добијених резултата из регресионе анализе.

Кључне речи: извоз, увоз, робне групе, конкурентност, пољопривреда

\section{Introduction}

The standard of living of an economy is the determinant of productivity, which measures the value of goods and services produced per unit of human capital and natural resources. (Porter, 2004) In other words, productivity depends on the value of national products and services, measured by prices on the open market, as well as the ability of the economy to mobilize human resources (Paraušić, 2007) in order to achieve a high income, a strong national currency and a high return on investment. (Porter, 2004) High technology led to a change in strategy to increase the productivity of companies, which make up one of the most important factors to increase the export potential of the country and improving competitiveness positions on foreign market. Porter is still in 1989 pointed out that the strategy of low labour costs, lowskilled workforce and exports of natural resources in an unprocessed form cease to be important and that their place is taken by the scientific and technical support workers and advanced infrastructure.

A survey conducted in 2003 in collaboration Jefferson Institute and the National Bank of Serbia, was aimed to show that Serbia is able to realize significantly higher than the current export succeeds, and the main problem cited lack of competitiveness not only in relation to the EU, but also in relation to the surrounding countries (Stamenković, et al., 2003). More than ten years have pointed to an increase in the value of the goods being exported to foreign markets means investing in the devastated economy of Serbia, which was believed to invest in equipment and technology, to increase the competitiveness of exports and conquer new markets. Although he then pointed out that the Serbian economy can not withstand the separation of budget and current consumption and at the same time set aside for investment, very little progress has been significant progress in terms of investment in industries that can be competitive on the international market and provide export significantly higher values. As a result of Serbia face heavy in the ranking of countries in terms of competitiveness WEF is very unfavorable. (Maksimović, 2012)

At the WEF (The World Economic Forum WEF) in 2013, a Serbia remains is ranked 101 on the list of 148 countries. Historical observed the highest value of 3.90 IGK Serbia has made on the eve of the first wave of the crisis in 2008, that the very next, 2009. The value of IGK noticeably dropped to 3.77. After this period, followed by a gradual recovery to the 2013 value IGK again descended to the level of 2009 (Tanaskovic, Ristic, 2013) Although the 2013 exports grew by $28.7 \%$ compared to $2012 \%$, while imports increased by only $8 \%$, (Chamber of Commerce of Serbia) remains the most important sectors of the Serbian economy: the basic manufacturing industries (metallurgy), leather, food and chemical industries. A particular problem is that a large part of the products of these sectors constitute the primary products with low added value (Presnall, 2006). One of the proofs is the Global Competitiveness Report in which Serbia in 2013/2014 evaluated in 3:01 with regard to innovation and the latter's place in relation to neighboring countries (Schwab, 2013). 
The researches presented in this paper are 30 commodity groups on the export side and 30 on the import of products, which constitute its most important parts, priced in US\$.

The aim is that based on regression analysis to evaluate the products that best explain the five-year period set model, and that the comparative analysis to determine whether there is a difference in the structure of the product to be exported or imported. In this way can be exported recommendations on additional investment in certain sectors of the economy and raising the level of analysis, which would both have a positive impact on increasing the value of export. In the other hand, through the analysis of the import commodity structure of recommendations can be made about some of the alternative products or commencement own production in those categories that the economy is to support primary resource.

General hypothesis:

- The null hypothesis 1 (H1o): The total exports are dominant commodity groups which include raw materials and intermediate products.

- The null hypothesis 2 (H20): In the total of imports are dominant product groups, which include raw materials and intermediate products.

Specific hypothesis

- $\quad$ The null hypothesis 3 (H30): There is no statistically significant effect of independent variables: $:^{3}$ coded-41,44, 48, 57, 58, 61, 81, 98, 111, 112, 282, 334, 335, 351, 421, 511, 542, 571, 581, 625, 641, 672, 673, 682.684, 691, 699, $716,764.781,846$, depending on the variable total exports.

- The null hypothesis 4 (H40): There is no statistically significant effect of independent variables: coded- 57, 333, 334, 342, 343, 351, 533, 542, 553, 554, 562, 582, 598, 641, 642, $676682,684,699,728,741,743,752,764,773$, $778,781,782,784,845,851,893$, depending on the variable total imports.

- $\quad$ The null hypothesis 5 (H50): There is no agreement in the movement of the annual rate of GDP per capita between Serbia and neighboring countries.

- $\quad$ The null hypothesis 6 (H60): There is a high correlation between total exports in 2013 and exports of passenger cars of the same year.

\section{Research mmethodology}

In addition to these specific null hypotheses in this paper are defined as other specific null hypothesis stemming from applied statistical and econometric methodology: regression and correlation analysis (hypotheses about multicollinearity, heteroscecasticity, autocorrelation and presumptions about the schedule of random error and its arithmetic mean, etc.).

Type of research and sample. Empirical analysis of the representation of certain groups of goods in total exports / imports was made for those product groups whose value exceeds US $\$$ od100.000.000. The basic technique of data collection is reduced to the analysis of data from the Republic Statistical Office of Serbia and database international various organizations such as the World Bank. For the regression analysis used data on exports and of imports by commodity groups annually. All product groups, with a value above mentioned, consist of independent variables in the regression model. Highlighted the 30 commodity groups, in order to select those that have the greatest impact on exports, and 30 products that have the highest influence on imports. All product groups are ordered from 1 to 999, and the names and codes of selected commodities for 
Reviewing will be shown in the tables attached. Take time to consider, from 2009 to 2013. interesting is because previous researchers have dealt with the analysis of the structure of exports by 2008/2009 and later analysis revolved solely on the comparison of figures without statistical analysis.

Statistical tools. All collected data is stored in a database Microsoft Excel 2007 and SPSS (Statistical Package for the Social Science for Windows, version 19). In this paper are used regression and correlation analysis. The collected data were statistically analyses using the program Statistical Package for the Social Science for Windows, version 19.0 - SPSS; (Pallant, 2011, Jovetić, 2007, Tabachnick \& Fidell, 2007). To determine the statistical significance level of trust was used $\alpha=0.05$.

\section{The results of the research}

\section{Indicators of economic competitiveness} indicators:

The competitiveness of the economy can be viewed through the next several

- Comparison of GDP per capita compared to neighboring countries, where according to GDP per capita, according to the Methodology and WEF, located on the middle level development ${ }^{4}$, in the second phase of development, whereas key drivers of competitiveness of the columns from the group factors increase efficiency. (Maksimović, 2012, p.102) of the gross domestic product in Serbia in 2012 amounted to US \$ 4943 per capita in comparison with neighboring countries, lower GDP / per capita have only Albania (3913 US \$), BH (4461 US \$) and Macedonia (4683 US \$). The higher GDP per capita in 2012 has Montenegro (6882 US \$), Bulgaria (7033 US \$), Czech Republic (US \$ 18,579) or Hungary (US \$ 12,736). (WEF, 2013, p. 333).

- Movement of foreign trade deficit in goods in the period 2009-2013 is in the range of 9.8 mil. to US \$ 14.6 million. US \$. ${ }^{5}$ In the first six months of 2013 foreign trade deficit reached 3.7 billion. US $\$$, a decrease of $13.5 \%$ compared to the same period in 2012. However, the value of the foreign trade deficit gives only a rough insight into competitiveness an economy. (Prausic, 2007) A more precise insight into the degree of competitiveness can be gained by analysing the structure of commodity exports. There should be noted that the dominant positions in Serbia's exports are iron, steel, non-ferrous metals, grains, vegetables and fruits. Regression analysis in the third part of the paper will be displayed variables (goods), that the five-year period has consistently greatest impact on export trends. The methodology of the International Trade Centre (ITC), which is applied to determine the best products and export sectors of the Serbian economy, has shown that the most important sectors of the Serbian economy: the basic manufacturing industries (metallurgy), leather, food and chemical industries (Presnall, 2006). From the report of 2006, no progress is made in changing the structure of exports and finding models to raise a level of processing, which would have a significant impact on the scaling up of export value. (Presnall, 2006) What is usually given as 
justification is the global financial crisis that began in late 2007, and today the majority of developed countries are past. The EU is an important trading partner of the United States so that the financial crisis in the United States worked to reduce the demand for imports of goods from the EU, causing a reduction in revenues from exports to the EU and therefore the reduction of EU imports, including imports from the countries of the Western Balkans and Serbian. (Jaćimović, 2013) The growth of exports over imports in 2013 could be an indicator of sunrise and Serbia from the crisis.

- Level of foreign debt is analyses on the basis of indicators that demonstrate the level of debt and the country's ability to meet its obligations under the external debt. Table 2 shows the ratio of external debt to the value of annual exports for the period from 2009 to 2012. This indicator with solvent countries does not exceed 220\%; you can say that in this five-year period the case with Montenegro, Bosnia and Macedonia.

Table 1: The ratio of external debt and the value of annual exports (\%)

\begin{tabular}{|l|l|l|l|l|}
\hline Year/Countries & 2009 & 2010 & 2011 & 2012 \\
\hline Serbia & 269.6 & 236.7 & 191.6 & 215.1 \\
\hline Romania & 254.7 & 226.3 & 186.4 & 203.7 \\
\hline Bulgaria & 223.3 & 175.4 & 129.0 & 145.4 \\
\hline Macedonia & 164.7 & 139.7 & 125.3 & 147.0 \\
\hline B and H & 218.3 & 180.9 & 159.2 & 182.9 \\
\hline Montenegro & 141.7 & 93.1 & 107.1 & 143.5 \\
\hline
\end{tabular}

Source: www.worldbank.org

What is the basis of the data analysis can be concluded is that all countries have the highest values of the indicators by 2009 had, which is considered the year in which the effects of the global financial crisis, the most visible.

Table 2 shows the percentage value of the ratio of external debt and annual exports, which according to the criteria of indebtedness by the World Bank methodology, should not exceed $80 \%$. The countries in which this indicator is above $80 \%$ belong to the group of highly indebted countries.

Table 2: The ratio of external debt and the value of annual exports (\%)

\begin{tabular}{|l|l|l|l|l|}
\hline Year/Countries & 2009 & 2010 & 2011 & 2012 \\
\hline Serbia & 85.5 & 91.2 & 75.1 & 94.8 \\
\hline Romania & 74.1 & 76.5 & 69.3 & 78.9 \\
\hline Bulgaria & 116.1 & 106.0 & 92.6 & 102.9 \\
\hline Macedonia & 56.8 & 58.0 & 61.4 & 70.0 \\
\hline B and H & 64.1 & 58.3 & 55.0 & 61.1 \\
\hline Montenegro & 54.0 & 40.5 & 54.9 & 68.3 \\
\hline
\end{tabular}

Source: www.worldbank.org

In addition to Serbia, which in 2011 alone was not highly indebted, there is Bulgaria, which although members of the EU, has an extremely high value of this indicator. What is the cause of the high value of this indicator in the case of Bulgaria, 
including Serbia, is the growth of external debt in ten years to several hundred times. ${ }^{6}$ The international financial institutions is generally accepted indicator of the relationship of annual commitments by external debt and the value of annual exports, according to which a highly indebted country if the annual amount of overdue principal and interest repayments exceed $25 \%$ of the value of exports of goods. (Marcetic, Đurić, 2012, p. 176)

Table 3: Ratio of annual obligations on external debt and the value of annual exports (\%)

\begin{tabular}{|l|c|c|c|c|}
\hline Year/Countries & 2009 & 2010 & 2011 & 2012 \\
\hline Serbia & 37.0 & 30.9 & 31.5 & 36.7 \\
\hline Romania & 34.7 & 33.8 & 27.4 & 34.2 \\
\hline Bulgaria & 21.9 & 14.4 & 12.2 & 13.0 \\
\hline Macedonia & 16.7 & 16.5 & 18.9 & 15.1 \\
\hline B and H & 9.1 & 14.6 & 13.6 & 18.4 \\
\hline Montenegro & 4.1 & 5.7 & 9.7 & 13.6 \\
\hline
\end{tabular}

Source: www.worldbank.org The World Bank

And according to this indicator, Serbia is one of the highly indebted countries, which in turn is a consequence of the above mentioned samples.

- Increase rates of inflation in the period from 2009 to 2013 shows significant fluctuations. What is a positive sign is the significant reduction in the rate of inflation in 2013, which is determined by comparing the first and second quarters of 2013 and second quarter of 2011. The following graph can be clearly observed prices of goods and services which had a lower growth in 2013 compared to the same period of 2011 and 2012. If we compare the first quarter of 2011, where the share price growth of unprocessed food was $5.5 \%$, while in the first quarter of 2013 , this percentage decreased to $1.1 \%$. Also, the smaller the increase in prices of processed food, energy industrial goods without food and energy, as well as services According to data from the National Statistics, this trend continued in 2014, with respect to the price of retail goods and services for personal consumption, on average, lower $0.3 \%$ in March compared to February of the same year.

\section{Regression analysis - the impact of individual commodity groups in export trends in the five-year period}

Based on theoretical and empirical analysis of each indicator of competitiveness, it can be concluded that the promotion of every important task of economic policy makers if they want to improve the competitive position of the Republic of Serbia. In this part of the paper will analyse the structure of exports, regression analysis to separate those commodity groups in the five-year period have the greatest impact on its movement.

Experimented with different curves regression analysis showed that the data is best adapted to the logarithm function. In the model, the other three variables, namely: commodity groups with the following codes: 41 (Wheat, shelled), 57 (fruit, fresh or dried) and 682 (copper). Data is adjusted and a linear function. In the model remain six variables, but linear hyper-flat surface is less Snedecor F statistics.

The statistical significance of the regression line is high, where Snedecor F random variable $\mathrm{F}=51.916 \mathrm{p}==$, 0006.Korigovan coefficient of determination (Adjusted $\mathrm{R}$ 
Square) is $92.7 \%$ and shows that $92.7 \%$ of the variation dependent variable - total exports explained variations of independent variable 41, 57 and 682. VIF for every variable is less than 5, it shows that there is no multi-collinear in the model.

It has been tested and heteroscecasticity problem. It is assumed that the random errors have constant variance and final. (Jovetić, Janković, 2012) was applied Gejslers test, the absolute value of the residuals are regressed in relation to the independent variable. Experimented with different curves and found that the data is best adapted to the exponential function. Stedekorov F statistic $F=1.896$ is smaller than $F(0,05 ; 1,4)$ $=7.71$ and $p=0.262$ is greater than $\alpha=0.05$, which means that the null hypothesis is accepted hypothesis, that there is no problem of heteroscedasticity.

We tested the assumption of compliance with the conditions of the random variable based on Kolgomorov-Smirnov test. Since the sig. $0.200(>0.05)$, to be adopted by the null hypothesis that the random variable can be approximated by a normal distribution. The arithmetic mean of residual deviations is equal to zero.

Table 4: Test of normality of the random variable

\begin{tabular}{|l|r|r|r|r|r|r|}
\hline \multicolumn{1}{|c|}{ Tests of Normality } \\
\hline & \multicolumn{2}{|c|}{ Kolmogorov-Smirnov } & \multicolumn{3}{c|}{ Shapiro-Wilk } \\
\cline { 2 - 8 } & Statistic & df & \multicolumn{1}{c|}{ Sig. } & Statistic & df & \multicolumn{1}{c|}{ Sig. } \\
\hline Unstandardized Residual &, 195 & 5 &, $200^{*}$ &, 909 & 5 &, 459 \\
\hline $\begin{array}{l}\text { a. Lilliefors Significance Correction } \\
\text { *. This is a lower bound of the true significance. }\end{array}$ \\
\hline
\end{tabular}

Source: Author

Based on the analysis, we can draw the conclusion that the three commodity groups that best helps to explain the model exported as raw materials. The first two are related to agriculture, which in 2013 recorded a surplus and one of the deserving branch impairment deficit compared to last year. Given that $75 \%$ of negotiations with the EU specifically related to agriculture and the environment, it can be said that this trend will be continued growth in exports, but with significantly raising the level of processing. Who can be concluded largest importer of fruit from Serbia is the Russian Federation, which has increased the import of fresh apples from Russia, in the period of 2008-2012, to 45\%. (International Trade Center) also increased exports of fresh apricots, cherries, peaches, nectarines, plums and sloes $21 \%$ in the same period. What are the analysis showed, and a chart where the growing trend is that the comparative advantage of Serbian agriculture and it certainly Fruit and Olericulture. Third significant variable in the export is copper ore, which is mostly exported to the Czech Republic, where the constant growth in demand. Pine Mine is one of the richest ore and this is considered to be still under-used, so that this branch of the economy has good prospects in the future.

\section{Regression analysis - the impact of individual commodity groups the increase in imports during the five year period}

For making a comprehensive analysis is necessary to perform an analysis of the commodity groups that have the most impact on the movement of imports in the period from 
2009 to 2013. Also, he experimented with different curves I regressive analysis showed that the data best adapted to the linear function. In the model, the other three variables, namely: commodity groups with the following codes: 343 (natural gas, liquid or not), 781 (passenger cars) and 351 (electricity). The statistical significance of the regression line is high, aSnedecorovs $\mathrm{F}$ random variable $\mathrm{F}=39.238 \mathrm{p}==$, 008. Korigovan coefficient of determination(AdjustedR Square) is $92.9 \%$ and shows that $92.9 \%$ of the variation dependent variable- total imports explained variations independently variables 343, 781 and 351 . The Also in this model VIF for all variables is less than 5, it shows that there is no multicollinearity. In order to determine that there is no problem of heteroskedasticity experimented with different curves and found that the data is best adapted to the exponential function. Stedekorova $F$ statistic $F=0.666$ is smaller than $F(0,05 ; 1,4)=7.71$ and $p=0.474$ is greater than $\alpha=0.05$, which means that the null hypothesis is accepted hypothesis, that there is no problem of heteroskecasticity Tested the presumption of compliance with the conditions of the random variable based on Kolgomorov-Smirnovth test. Since the sig. 0,110 (>0.05), adopts the null hypothesis that the random variable can be approximated by a normal distribution. The arithmetic mean of residual deviations is equal to zero.

Table 5: Test of normality of the random variable

\begin{tabular}{|l|r|r|r|r|r|c|}
\hline \multicolumn{1}{|c}{ Tests of Normality } \\
\hline & \multicolumn{3}{|c|}{ Kolmogorov-Smirnov $^{\mathrm{a}}$} & \multicolumn{3}{|c|}{ Shapiro-Wilk } \\
\cline { 2 - 8 } & Statistic & \multicolumn{1}{c|}{ Df } & \multicolumn{1}{c|}{ Sig. } & Statistic & df & \multicolumn{1}{c|}{ Sig. } \\
\hline $\begin{array}{l}\text { Unstandardized } \\
\text { Residual }\end{array}$ &, 318 & 5 &, 110 &, 830 & 5 &, 140 \\
\hline \begin{tabular}{l} 
a. Lilliefors Significance Correction \\
\hline
\end{tabular}
\end{tabular}

Source: Author

Based on the analysis we obtained three commodity groups that consistently best explain the dependent variable, i.e. total imports. In the first place the gas, which is mainly imported from Russia and Kazakhstan, as the graph can notice. Annual expenditures for both types of energy on average amount to about 3,000 per year per household. This amount alarms need to develop capacity for the production of renewable forms of energy, especially those based on solar light. Interesting is the third separate variables, cars and to those from 1000 to 1500 cubic meters, have a large share in total exports, as the graph can observed. The largest exporter of this group of cars on the Serbian market is the Czech Republic and Slovenia. Cars from 1500 to 3000 cubic meters of mostly imported from France and Germany. The high value of the imported commodity groups can be compensated for by exports of Fiat cars, which in 2013 had the largest share in total exports of US \$ $1946612000.2(9.5 \%)$. However, it is mostly exported to that group of vehicles (from 1000 to 1500 cubic meters), which is most common in the total imports. The US \$ 1.256136 billion exports are cars from 1000 to 1500 cubic meters. This group of car exported to the US and Italian market. 


\section{Comparative analysis of results obtained from the regression analysis}

The importance of comparative analysis of exports and imports shows the Spearman correlation coefficient, which measures the ratio of export and import of Serbia in the period from 2001 to 2013. It is very important to make a comprehensive study in order to draw conclusions about the structure of these two indicators and Manner of their equalization priced.

Table 6: Spearman correlation coefficient for exports and imports in the period from 2001 to 2013

\begin{tabular}{|c|c|c|c|}
\hline \multicolumn{4}{|c|}{ Correlations } \\
\hline \multirow{3}{*}{ Spearman's rho } & \multirow{3}{*}{ total exports per year } & Correlation Coefficient & $912^{* *}$ \\
\hline & & Sig. (2-tailed) &, 000 \\
\hline & & $\mathrm{N}$ & 13 \\
\hline
\end{tabular}

Source: Author

The null hypothesis is that general are dominant in the total export commodity groups that include raw materials and intermediate products, which can be adopted with respect to the entries model best explains the three variables, wheat, fruits and copper. These three commodity groups fall in raw materials and exported in its basic, raw material form (adopted by the general null hypothesis $\mathrm{H} 01$ and $\mathrm{H} 31$ specific alternative hypothesis). Although in 2013, the largest share in total exports was the automotive industry, as evidenced by the Spearman correlation coefficient with a value of 1 , regression analysis has provided aside from the aforementioned three variables as those that best explain the model. After examining the database Republic Bureau of Statistics clearly show that the growth in exports of passenger cars bound for the 2012/2013 year, we can derive the reason of the foregoing (adopt the alternative hypothesis H61).

Table 7: The value of exports of passenger cars in the period from 2009 to 2013

\begin{tabular}{|l|l|l|l|l|l|}
\hline Commodity Group / year & 2009 & 2010 & 2011 & 2012 & 2013 \\
\hline Passenger cars & 15839,5 & 39311,3 & 51474,4 & 397856,0 & 1946612,2 \\
\hline
\end{tabular}

Source: Republic Bureau of Serbia

Also, the null hypothesis that the general in the total exports of the dominant commodity groups which include raw materials and intermediate products can not be confirmed, since the regression analysis showed that the sutras dominant commodity groups represented in imports in the reporting period, gas, electricity and passenger cars. It was found that $92.9 \%$ of the variation dependent variable- total imports explained variations of the above independent variables (adopted by the general alternative hypothesis $\mathrm{H} 12$ and $\mathrm{H} 41$ specific alternative hypothesis). 


\section{Conclusion}

Based on the research, the analysis of the survey results and statistical and econometric analysis, the following can be further directions of analysis:

- The main limitation is the lack of labor statistics and econometric analysis only on the Serbian economy. The analysis should be extended, in accordance with the theoretical part of the work to other countries in the region.

- Given that the work of statistical data for the period from 2009 to 2013, the analysis could be extended to the ten-year period on the basis of which they could draw conclusions on the change of the export / import structure.

- $\quad$ The paper conducted two regression analysis and by 30 commodity groups to stop imports and 30 commodity groups in exports with a share of more than US \$ 100 million, so that the analysis could be extended to those commodity groups in total export / import feature the participation of more than 50 million US \$.

- The theoretical part of the work could be completed with some other indicators of competitiveness in its methodology used by the World Bank. The paper analyses the macroeconomic environment has been reduced and could be extended to institutions (first pillar). This segment is very important with regard to his analysis came to the core of problems plaguing the economy of Serbia to be further developed. A World Bank report states that the importance of a healthy and fair institutional environment a key item out of the crisis, strengthening the economies of developing countries and their integration into the international mainstream.

Based on the analysis can be applied to make the following recommendations:

- Regression analysis has provided showed that fruits and grains have the greatest impact on constantly trend export so that the recommendation to invest more in this industry, which at this level shows excellent results. Especially important is the relationship with Russia, given that the percentage increase in the export of fresh fruit to this market increased significantly in recent years and has the potential to continue this trend. Recommendations for consolidation of parcels and the adoption of a strategic plan on the way of financial assistance to registered farms.

- In addition, regression analysis showed that the most consistent impact on import trends have energy (electricity and gas), therefore it is necessary to make a long-term plan for the production of renewable forms of energy, especially those based in the sunlight.

\section{Reference}

Aranderenko M. (2011), Utility strategy for recovery from the crisis in South East Europe, Assessment Study: Serbia, International Labour Organization, Tim for technical support decent work and Office for Central and Eastern Europe, Budapest, Hungary

Auboin, Marsch (2004), The Trade, Debt and Finance Nexus: at the Cross-roads of Micro- and Macroeconomics, Discussion Paper No 6, World Trade Organization, Geneva, Switzerland, p. 1-32 
Ristić, B. Tanasković S., (2013). Competitive position of Serbia in 2013. According to the World Economic Forum. The Foundation for the Advancement of Economics, Belgrade.

Bruneckiene, J., \& Paltanaviciene, D. (2012). Measurement of export competitiveness of the Baltic States by composite index. Engineering Economics, 23(1), 50-62.

Đuričin D. Petraković D., (2003), “The New Competitive Strategy of Serbia”, in: Danilo Šuković (ed.), Competitiveness and transition, Association of Economists of Serbia and Montenegro, Proceedings of the necessarily-professional consulting economist Serbia and Montenegro Belgrade, p. 31-42

Internet sources:

Jovetić, S., Janković, N. (2012). Knowledge and innovation as a factor of socioeconomic development: statistical and econometric model, Economic Themes, 50(4). 511-533.

Kovacevic, R. (2006), Possibilities and limits the increase in the balance of payments export as factor Serbia, Original research article, available on http: //www.doiserbia.nb.rs/img/doi/0025-8555/2006/0025-85550604492K. pdf, (25.03.2014)

M. Porter, K. Schwab, Sorrell M. Lopez and AC (2004) Book: The Global Competitiveness Report 2004-2005, Palgrave Macmillan, New York.

Maksimović, L. (2012). Sistemska ograničenja konkurentnosti privrede Srbije. Ekonomski horizonti, 14(2), 99-109.

Marčetić M. Djuric O. (2012). Analysis of the debt of the Republic of Serbia and its methodological guidelines, Journal of Economics and Marketing Communications, No. 2, pp. 274-291.

Myers, M. B., \& Harvey, M. (2001). The value of pricing control in export channels: a governance perspective. Journal of International Marketing, 9(4), 1-29.

Pallant, J. (2011), SPSS Survival Manual: A step by step guide to data analysis using SPSS, Open University Press, McGraw-Hill, Berkshire, UK.

Paraušić, V. (2007). Institutional and infrastructure barriers to competitiveness of the Republic of Serbia. Medjunarodni problemi, 59(4), 597-626.

Republic Statistical Office of the Republic of Serbia, available at http://webrzs.stat. gov.rs/WebSite/

Schwab, K. (2014), The Global Competitiveness Report2013-2014Full Data Edition, http://www3.weforum.org/docs/WEF_GlobalCompetitivenessReport_2013-14.pdf 16th International Trade Centre, available at http://www.trademap.org/

Stamenkovic, S., D. Savin, M. Kovacevic, M. Vuckovic, Vukotic-Cotič G., M. Maksimovic, I. Nikolic, Mr. Petković, Kozomora J, P., K. Ognjenovic, Brankovic A. Jovanovic I., Gajić D.( (2003), Competitiveness of Serbia, Jefferson Institute, Belgrade.

The World Bank (data), available at http://data.worldbank.org/ 


\section{Endnotes}

3 Independent variable is given in the form of codes, which will be explained at the end of the attachment.

4 This group includes all countries with a GDP per capita of US \$3000-8

5 External trade R. Serbia, December 2013., National Bureau of Statistics of Serbia.

6 External debt of Bulgaria in 2000 was 10.4 billion. US \$, while the 2011 rose to 46.6 billion US \$. 